\title{
Orthography Analysis-Spanish Graphical Accentuation Setting
}

\author{
Joel Laffita Rivera \\ Correspondence: Joel Laffita Rivera, Faculty of Applied Communication (FAC), Multimedia University, Malaysia.
}

Received: August 22, 2019

doi:10.11114/ijce.v2i2.4528

\author{
Accepted: September 9, $2019 \quad$ Online Published: September 16, 2019
}

URL: https://doi.org/10.11114/ijce.v2i2.4528

\begin{abstract}
This research article is setting up an outlined-linguistic-overview regarding to the use of the "Tilde" in the writing context of Spanish Language. The study looked over various-literature-materials from different sources and added new-insights into its contextual framework to expose Spanish-language-Orthography such as Words-Type; Accents-Type; Vocabulary and Grammar-Patterns. The use of the "tilde" in teaching and learning Spanish as Second Foreign Language (ELE) continue to be a focus of concern and discussion among Spanish language teachers as well as the learners of this particular foreign language subject (FLs). Numerous studies have emphasized on the need to provide accuracy-learning-materials in relation to this orthography-linguistic-trait. Consequently to this observation, the study aimed to deliver valuable text-references through which Spanish language learners know about the application of the "Tilde" in the writing system of Spanish language. Furthermore, methodological schemes are provided to assist Spanish language teachers in formatting and delivering Spanish-language-assignments that fit into the subject-matter-discussed.
\end{abstract}

Keywords: orthography, wordlist, phonetic, analogy, teaching, learning

\section{Introduction}

Orthography is a set of conventions for writing a language. It includes norms of spelling, hyphenation, capitalization, works-breaks and punctuation. Spanish has an official body (Royal Spanish Academy) that governs linguistic rules, orthography among them ${ }^{\text {I}}$ Ortografía de la lengua Española, 2010). According to the Royal Spanish Academic Spanish Orthography is the orthography used in Spanish language. This statement might be seen as a redundant-quotation but it clearly defines the authenticity of the subject-matter it refers. The use of the "tilde-Acento Ortográfico" as it is linguistically known in Spanish is one of the most relevance linguistic-aspects that characterize the Writing System of Spanish Language. Starting from the Spanish Alphabet the distinct used of the tilde (ñ), which differentiates this letter from the letter (n) outlining that way the writing and verbally spelling of many Spanish words, among them (España) / (Lengua española) / (Idioma español) ext. Even though all graphical accents are called "tildes" in Spanish; they are named differently. Such as are the cases of the "Acute Accent-Acento Prosódico" about which the use of the "tilde" is placed over any vowel: (á é í ó ú) to mark the tonic-stressed-syllable. Regarding to this specific accent it is necessary to know which the "four-Spanish-words-type" are to recognize how to pronounce Spanish-words with the lack of the graphical-accent "tilde" too. These four words-types are classified according to rules and exceptions that govern the use of Spanish language in this respect. The other two ways of accentuation are "the diacritic tilde" which is typically placed on homophones (tú-tu / él-el / mí-mi / té-te / intérprete / interprete / interpreté) ext. and the "diaeresis" (ü) used in the sequences (güe) and (güi) to distinguish it from the unmarked same syllable (gue) and (gui), and as a prerogative of literature-poetry in order to break the diphthong and add to the verse one more syllable: iQué descansada vida la del que huye del mundanal ruïdo...! ${ }^{2}$ (Fray Luis de León, 1631). Orthographically, these Spanish peculiar ways of accentuation play indispensable role in distinguishing the writing and pronunciation of Spanish-words and Spanish-words-syllables. Taking into account this general prospect-Introduction, the study is displacing the following Headings and Sub-headings.

\section{Study Based-Concern-Facts}

The use of the "tilde" in teaching and learning Spanish as second foreign language is often treated as a point of

\footnotetext{
${ }^{1}$ Ortografía de la lengua española (2010). Real Academia Española y Asociación de Academias de la Lengua Española. p. 63.

${ }^{2}$ La Vida Retirada (1631). Fray Luis de León (español).
} 
misconception. The treatment of language-errors in second-language-acquisition has become in many cases an issue to not be addressed to avoid the reflexed-affliction it could have on the learners-learning-sensitiveness. Conceptually, this view makes sense, nevertheless, referring to the use of the tilde in the writing context of Spanish Language, mainly the use of "graphical tilde" the reality behind is that the lack of knowledge concerning to it is the mayor problem, and in this respect Spanish learners seem to be comfortable with it as long as it does not affect the marking-grades. However, stress in Spanish is functional: to change the placement of stress changes the meaning of a sentence or phrase ${ }^{3}$ (Eddington David, 2004). When it comes to writing and pronunciation we should be aware that the lack of the tilde on a Spanish word that requires it can change the intent-meaning of the speaker whether in writing of verbally spelling out much of the Spanish statements. For instance, ¿Cuántos anos tienes? Instated of ¿Cuántos años tienes? / Tengo 20 anos. / Instated of Tengo 20 años. / Mi papa está... / Mi papá está... (Marked-accent-meaning-pronunciation) / Mama... (A verb-command-form). / Mamá (noun). Mamá mía.). Academically, the use of this marked-accent is frequently a questionable topic among Spanish language learners, mostly the novices. Questions such as What that accent means? / How do I know when to use it? / Will my points be deducted if I do not use it? are often asked in Spanish beginners FL classes. This realistic-academic-issue is connecting to answers that cannot be probably found in the Spanish language manuals that we are using. So, most scholars and students of Spanish Language do not address the use of the tilde in the writing and speaking context of Spanish language as a point to be seriously focused. Emphasizing on the significant of teaching and learning "Spanish language specific characteristics" (Rivera, 2019) cites that the current way to do is impacting the teaching of Spanish as second foreign language and in terms of properly acquiring it is causing adverse effects to the mind of $2 \mathrm{~L}$ learners leading to distortion and inadequate Language-Learning-Retention. Working with Spanish learners whose native-language does not possess linguistic characteristics such as written-accents as Spanish does it is a complex and difficult subject-matter to comprehend and digest. It is a challenge dilemma which lets us with not option that emphasizing on the significant of the use of the "tilde" in the Writing Context of Spanish Language.

\section{Orthography Words-Category-Setting}

When it comes to words-types, unlike other languages Spanish uses four types-words-categories according to the Writing System of this language. These words are called: (Agudas; Llanas or Graves; Esdrújulas and Sobresdrújulas). All these words are stressed one way or the other with written accent "tilde" (Acento Ortográfico) or "Acute Accent" (Acento Prosódico) depending on the stressed-syllable. Consecutively with this, the application of these kinds of accents is subject to rules and exceptions that govern this Spanish-language-orthography-trait. According to what the rules prescribe; if the last syllable is stressed it falls into the aguda category. Aguda words generally end in a consonant other than $n$ or $s$, or are a conjugated verb that ends in an accented, stressed vowel. If the stress falls on the second to last syllable, it is classified as a llana or grave. Llanas typically are words that end in $n, s$, or a vowel. Any exceptions have a written accent. If the stress is placed on the third to last or the fourth to last syllable, they are categorized as esdrújulas or sobresdrújulas, respectively. In either of the last two categories, the stressed syllable must be accented to break the rules of the first two categories ${ }^{5}$ (Joshi, 2006). The examples below illustrate the subject-matter highlighted:

\section{Word Categories Examples}

Agudas

Cantidad / pared / reloj / mentol / azul / sonreír / volarán / baúl / raíz / maíz

\section{Llanas or Graves}

Decían / engañaba / Fernández azúcar / almíbar / cárcel / huésped / inútil / imbécil

Esdrújulas

Décimo / máquina / teléfono / música / página / médico / fábricas / únicos

\section{Sobresdrújulas}

Alcáncemelo / déjesela / dígamelo / prohỉbanselo / regálenmela / tráiganosla

\section{Orthography Lexicon-Setting}

\footnotetext{
${ }^{3}$ Eddington David, 2004). Spanish Phonology and Morphology: Experimental and Quantitative. p.120. ISBN 9789027215628.

${ }^{4}$ Rivera, J. (2019) Spanish Language Grammatical Context-Acknowledging Specific Language Characteristics. Open Journal of Modern Linguistics, 9, 215-228. doi: 10.4236/ojml.2019.93020.

5 Joshi, R. Malatesha; Aaron, P. G. (2006). Handbook of Orthography and Literacy. p. 157. ISBN 9781136610813.
} 
According to a statement quoted in ${ }^{6}$ (English Oxford Living Dictionaries, 2018): "vocabulary is defined as the body of words used in a particular language, which origin is dated back to the Mid- $16^{\text {th }}$ Century (denoting a list of words with definition or translation): from Medieval Latin vocabularies, from Latin vocabulum". I do agree with that statement, seen from a linguistic-perspective I would say that vocabulary is "any word, including those we classify by using the term "grammar". Thus, whether the words used belong to vocabulary or grammar (café / violín / volcán / estás); acknowledging the words-type and the issues concerning to them in Spanish it will provide deep understanding about the use of the written and no written accents in this language. The examples to be cited regarding to vocabulary with written-accent-tilde are of a wide-range of linguistic-traits. For instance, we observe the use of the tilde in Cardinal Numbers (16 dieciséis / 21 veintiún / 22 veintidós / 23 veintitrés / 26 veintiséis). These are the cardinal numbers with written accent. Because of "gender and agreement" the number (21 veintiuno) is shorted to (veintiún) when it is used before a masculine-noun, manly by speaking (Yo tengo 21 años de edad. / I am 21 years old.). We also see the use of the tilde in Ordinal Numbers $\left(7^{\text {th }}\right.$ séptimo $/ 10^{\text {th }}$ décimo $/ 11^{\text {th }}$ undécimo $/ 12^{\text {th }}$ duodécimo $/ 17^{\text {th }}$ decimoséptimo $/ 20^{\text {th }}$ vigésimo / $23^{\text {th }}$ trigésimo / $40^{\text {th }}$ cuadragésimo / $50^{\text {th }}$ quincuagésimo / $60^{\text {th }}$ sexagésimo / $70^{\text {th }}$ septuagésimo / $80^{\text {th }}$ octogésimo $/ 90^{\text {th }}$ nonagésimo $/ 100^{\text {th }}$ centésimo). Notably, all these ordinal numbers have the written accent on the (é), which is a point of memorization, particularly for Spanish beginner's learners. A part from this, we also see the use of the tilde in Days of the Week (miércoles / sábado Wednesday/Saturday), about which is nice to know that the days of the week are not written with capital letters in Spanish. ${ }^{7}$ (Gerald Erichsen, 2012) argues that one key to expanding Spanish vocabulary quickly, especially as beginners, is learning to recognize the word patterns seen in many English-Spanish cognates. I do agree with that research-academic-opinion. In that respect inducting the notion of the use of the written-accent-tilde is a matter of applying linguistic based on analogies between languages; for instance, (education/educación / profession/profesión / crucifixion/crucifixión). Remarkably, all English-vocabulary with this similar-writing-orthography have their Spanish counterpart with written-accent-tilde in the way highlighted (globalization/globalización / administration/administración / revolution/revolución).ext. So, in this way (syllable-written-accent) we can also outline others words-vocabulary such as (marrón / brown) / avión / camión / airplane/truck) ext.

\section{Orthography Syntax-Setting}

The following statement quotes that grammar is part of Linguistics which studies the elements of a language as well as the way in which these are organized and combined ${ }^{8}$ (dictionary of the language Spanish 23rd edition, 2015). Considering the words-intent-meaning "organized and combined" we can emphasize on Spanish grammars that require the use of the written-accent in order to provide appropriate insights that lead to the comprehension of this Spanish-orthography-trait. For instance, the subject personal pronoun "túlyou" and "tulyour" possessive adjective (Tú tienes tu clase de español ahora.); the pronoun "mi" and "mi" possessive adjective (A mi me encanta mi clase de spañol.); interrogative words such as "qué / por qué / cómo / cuándo / dónde / cuál (que-pronoun / porque-preposition / como-adverb and verb / cuando-adverb / donde-adverb / cual-pronoun) ext. These words are monosyllables which generally are not written with written-accent in Spanish; however, in all of them we can see the presence of identical-grammar-shapes distinguished by the use of the written-accent-tilde only. Consequently to this point we can tap also into the possessive pronouns (mío / mía-mine) which are also monosyllables marked by the use of the tilde too. This is the function of the "diacritic tilde" when it comes to Spanish-grammar-monosyllables-words. Continually we can see the use of the tilde in many others Spanish grammar such as the "verb-conjugated-forms" for the subject personal pronoun yo/I in Preterit Perfect: (trabajé. / comí. / viví.). The "verb-conjugated-forms" for the subject personal pronoun yo/I in Preterit Imperfect: (hacía. / vivía.). In this aspect the "verb-conjugated-forms" for the subject personal pronouns él/ella/usted/he/she/you in Preterit Perfect: (trabajó. / comió. / vivió.). The "verb-conjugated-forms" for the subject personal pronouns él/ella/usted/he/she/you in Preterit Imperfect: (hacía. / vivía.). The two verb-forms in Preterit Imperfect belong to the Spanish-infinite-verb-forms ending in "er" and "ir" (hacer/vivir). Regarding to "Infinite-verb-forms" we can highlight the few that exist in Spanish grammar with written-accent: (reir / freir / oir), which is a point of memorization. The Preterit Perfect verb-forms illustrated include regular and irregular verbs. In the case of verb-forms for the subject personal pronouns él/ella/usted/he/she/you the use of the tilde differentiates these verb-forms from nouns and verb-forms in present indicative and preterit perfect (El público. / Usted publicó./ Yo publico.).

\footnotetext{
${ }^{6}$ English Oxford Living Dictionaries (2018).

${ }^{7}$ Gerald Erichsen (2012) Grammatical Differences Between Spanish and English.

${ }^{8}$ Diccionario de la lengua española 23a Edición, 2015). Madrid: Espasa. ISBN 978-84-670-4189-7
} 


\section{Orthography Pronunciation-Setting}

Although the vocabulary and grammar of Spanish language possess a complex lexicon-variations; grammatical-structures and linguistic-applications correspondingly; phonetically, Spanish is one of the easiest foreign languages to learn. For instance, English native speakers can take advantages from the linguistic-analogies between Spanish and English to acquire and develop language-competences. ${ }^{9}$ (Carlos, 2002) quotes that "there are many similarities between English and Spanish, both languages use the Roman alphabet and that knowledge helps build a phonemic and phonological foundation". Similarity, ${ }^{10}$ (Jerry K. Blackburn, 2015) cites that learning the Spanish alphabet requires only learning three more letter than are found in the English alphabet. These include ch (che), 11 (elle) and $\check{n}$ (eňe). However, when it comes to the use of the "tilde" it is not a wonder to see the alphabet letter ( $\tilde{n}$ ) as a reference-learning-focus. This is the only-consonant with a written-accent in Spanish, this alphabet letter is known in English as "n with a tilde". The use of the tilde on this consonant as well as the use of the other kinds of tildes (álélílólú/ï) must be a writing-language-focus when studying Spanish language because of meaning-changes as stated in prior statements, and phonetic-implications: (Feliz cumpleaños. / Feliz Año Nuevo. / Hasta mañana. / Mañana por la mañana.). Acá. Aquí. /¿Qué tienes? / ¿Qué lindo! / ¿Cómo! / Intérprete. / Interpreté. / Bilingüe. / Lingüística. ext. In terms of "punctuation" there is a phonetic-connection that involves the use of the question-marks and the tilde in Spanish. ${ }^{11}$ (Agustin, 2014) cites those question-marks related to this insight: "the unusual feature of indicating the beginning of an interrogative or exclamatory sentence or phrase with inverted variants of the question mark and exclamation mark $\langle i\rangle$ and $\langle i\rangle$, respectively. Most languages that use the Latin alphabet (including Spanish) use question and exclamation marks at the end of sentences and clauses. These inverted forms appear additionally at the beginning of these sentences or clauses". In this regard the examples above-provided can speak about what is stated. As can be observed, the Spanish-Language-Orthography related to the use of tilde in the Spanish-Language-Writing-Context is a complex subject-matter, which from the standpoint of methodology requires also special treatment to be addressed.

\section{Methodology}

When it comes to "Spanish Orthography", especially the use of the "Tilde/Acento Ortográfico", we have to seriously consider the kind of method we set to teach it. As labeled in the previous heading-insights of this research article there are so many things that need to be studied in relation to this subject-matter. This is a topic that involves a huge amount of complex-orthography-linguistic-aspects which cannot be compiled in a single-research-article. Those that have been exposed in this manuscript make up just a part of that vast-orthography-field. So, the methodology-schemes provided-below are direct to help Spanish language teachers setting up Spanish-language-assignments to transfer knowledge regarding to the use of the tilde in Spanish-Writing-Context. These assignments will help Spanish leaners acquiring and developing cognitive-skills and language-competences. These method-tasks are in line with what is prescribed in ${ }^{12}$ (Consejo de Europa, 2001) Marco Común Europeo de Referencia para las Lenguas: aprendizaje, enseñanza, evaluación to access Spanish language learners in level A1 which according to the ${ }^{13}$ (American Council on the Teaching of Foreign Languages, 2012) (ACTFL) on the Teaching of Foreign Languages is the equivalent-level of Novice Low and Mid. So, we begin with THE TILDE NOTION, inducting the notion of the use of tilde in teaching Spanish is not a difficult-task to conduct. Due to the own-language-orthography-characteristics the use of tilde is revealed from the very beginning of the teaching and learning process of this discipline: Greeting-Lesson for instance, the use of the tilde in interrogative-words-sentence-structure which is an obligatory-Spanish-orthography-usage in these cases is a good reference-point to begin addressing this topic by proving (writing and pronunciation) explanations, and setting exercises accordingly. For instance, (cómo / qué) interrogative-words / (como / que) abverb and verb and pronoun: ¿Cómo te llamas? In contrast Yo soy como mi padre. Yo como pan. $/$ ¿Qué tal? In contrast Que tengas un buen día. By doing these kinds of practical-exercises learners will get insights about the use of the tilde (meaning and differentiation) and question-marks from the very beginning of the Spanish language teaching.

LINGUISTIC-ANALOGY, when working with Spanish language learners whose native-language share with Spanish

\footnotetext{
${ }^{9}$ August, D., Calderón M., \& Carlo M. (2002) The Transfer of Skills from Spanish to English: A Study of Young Learners. Center for Applied Linguistics, Washington, D.C.

10 Jerry K. Blackburn (2015). An Easy Comparison Of The English to Spanish Alphabet.

11 Capitalization". The Writer's Reference Guide to Spanish. Austin: University of Texas Press. pp. 75-77. ISBN 978-0-292-72511-9. Retrieved September 18, 2014.

${ }^{12}$ Consejo de Europa (2001). Marco Común Europeo de Referencia para las Lenguas: aprendizaje, enseñanza, evaluación. https://www.examenglish.com/CEFR/cefr_es.php

13 American Council on the Teaching of Foreign Languages, 2012) (ACTFL
} 
Latin-Origin; the matter is applying linguistic-similarities in language-teaching. For example, Spanish/English obi-verse; regarding to the use of the tilde we provide a wordlist which spelling is similar in writing and meaning in both languages in order to capturing attention and learning-engaging referring to the subject-matter: education/educación / profession/profesión formation/formación / pronunciation/pronunciación ext.

SYLLABLE DIVISION, phonetically, the best way of addressing the tildes-use is through the syllable-division, which is a topic that can be introduced during the lesson about the Spanish Alphabet. For example, the teaching of vowels (a/e/i/o/u) / (á/é/i/ó/ú) / (ii) with written and no written accents. Dividing a Spanish-word into syllables requires knowing the basic rules:

1. Do not separate the group of consonants $(b, c, d, f, g, p, t)$ followed by the consonants ( $l$ or $r$ ).

2. Do separate any other syllable-groups.

3. Think in mind that a "vowel" can constitute a syllable.

Examples

$$
\begin{gathered}
\text { Bicicleta / bi-ci-cle-ta } \\
\text { Melodrama / me-lo-dra-ma } \\
\text { Fluye / flu-ye } \\
\text { Negro / ne-gro } \\
\text { Placer / pla-cer } \\
\text { Otro / o-tro } \\
\text { Muchacha / mu-cha-cha } \\
\text { Chaqueta / cha-que-ta } \\
\text { Amarillo / a-ma-ri-llo } \\
\text { Brillar / bri-llar / } \\
\text { Terrible / te-rri-ble / } \\
\text { Aburrido / a-bu-rri-do } \\
\text { Alto / al-to / } \\
\text { Calcetín / cal-ce-tín / } \\
\text { Castaño / cas-ta-ño / } \\
\text { Bilingüe / bi-lin-güe / } \\
\text { Pingüino / pin-güi-no }
\end{gathered}
$$

COMPUTER LANGUAGE ASSISTED, apart from the methodologies-above-provided; the study is also providing insights in relation to the use of the written-accent and punctuation through Typeset Setting: To write Spanish on a typewriter or to set type, the special characters required are $a, e ́, i, \delta, \dot{u}, \tilde{n}, \tilde{N}, \ddot{u}, \ddot{U}, \dot{\iota}$, and $i$. The uppercase $A ́, \dot{E}, \dot{I}, \dot{O}$, and $U$ are also prescribed by the RAE, although occasionally dispensed with in practice. As implemented on the mechanical typewriter, the keyboard contained a single dead key, with the acute accent (') in the lowercase position, and

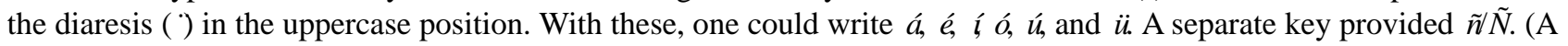
dead key " $\sim$ " is used on the Spanish and Portuguese keyboards, but on the Latin American keyboard the " $\sim$ is not a dead key). The inverted marks " $i "$ and " $i "$ completed the required minimum. The diagram: Microsoft Word Document-Tilde Guide shows the necessary steps that one can follow to obtain and use all the Spanish-graphical-accents and punctuation here stated: 


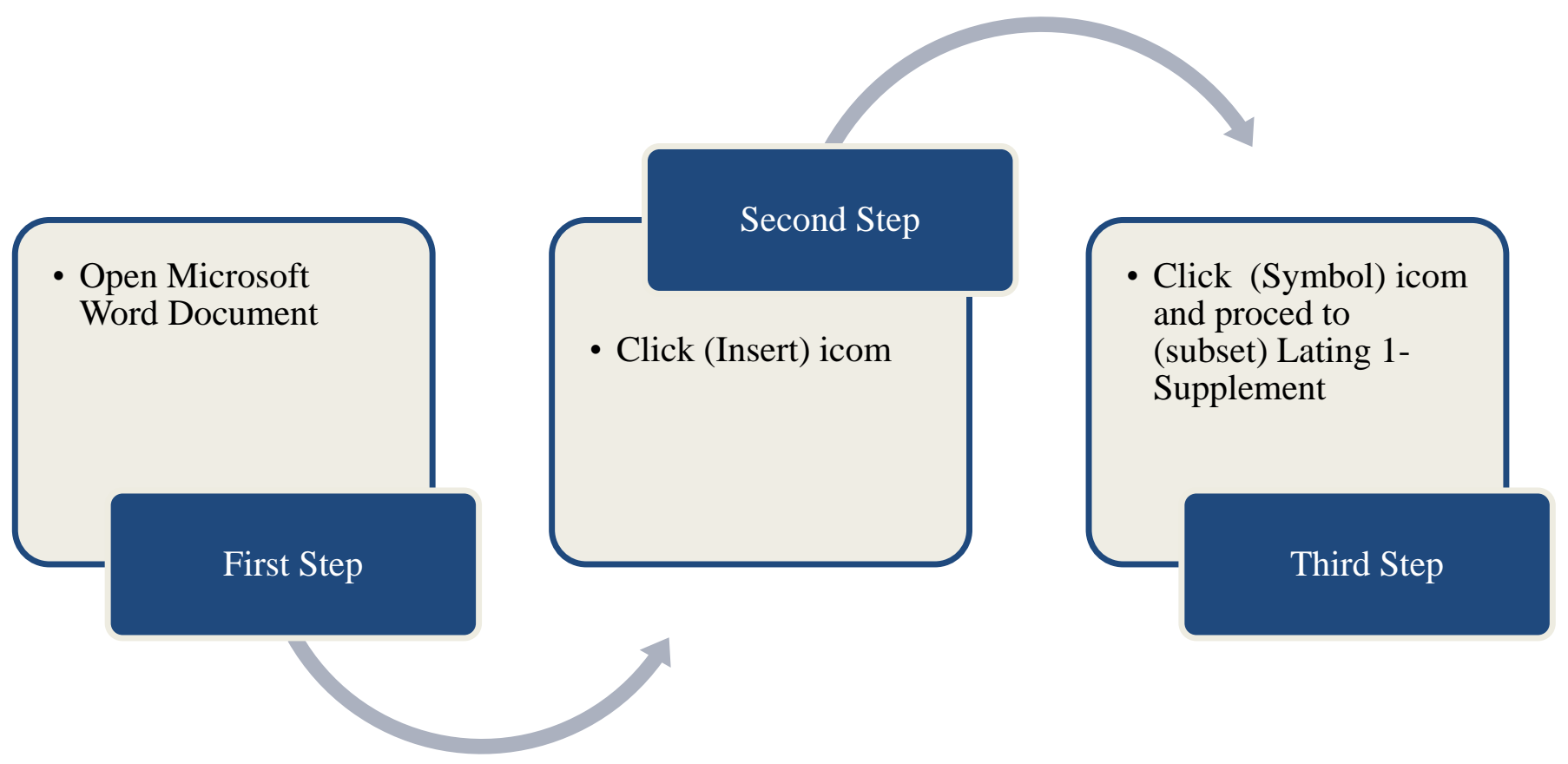

Microsoft Word Document-Tilde Guide

\section{Objective of the research}

The core intention of this study has been to deliver valuable text-references through which Spanish language learners know about the application of the "Tilde" in the writing system of Spanish language and to provide methodological schemes to assist Spanish language teachers in formatting and delivering Spanish-language-assignments that tap into the subject-matter-discussed. Lining to the main objective the manuscript has displaced throughout its headings and sub-headings significant among of collected and added data to contextualize its framework. In order to corroborate confidentiality and validate the research-finding; the results; discussion and conclusion as follow:

\section{Results and Discussion}

This study was conducted based on observations in teaching and learning Spanish Orthography on the subject of Graphical-Accentuation, particularly the "tilde-Acento Ortográfico", "Acute Accent-Acento Prosódico" and the "Diaeresis" (ii) in Spanish language classes conducted at Multimedia University (MMU), Malaysia. These observations were based on analyzing the use of these tildes in the writing context of Spanish language. The centered-topic was the role of these kinds of graphical-accentuations in Spanish language. Thus, the study capitalized on Spanish Linguistic Aspects such as Word-Types; Vocabulary; Grammar and Pronunciation that implied the use these tildes. The results of this study showed that Spanish language learners whose native-language does not apply these graphical-accentuation-forms the way Spanish does are prone to commit mistakes in applying them in the writing context of Spanish language. Even though this is an expected result from Spanish 2L learners, mainly from the novices; the Spanish language tilde-trait involved is a topic of concern due to the writing-differentiation; meaning-differentiation and phonetic-differentiation impact that these graphical-forms of accentuation have in Spanish Language. This study considers that reasons for this happens can be traced to factors such as the inference of the L1-mind-subconscious which does not apprehend such linguistic-trait due to the incompatibility between the L1 and L2; Insufficient knowledge about the usage of graphical-accentuation in Spanish language; The design of specific teaching and learning Spanish Graphical-Accentuation-Lessons to overcome the challenges that the current grammar teaching methodology (grammar must be acquired by students in an inductive way) suggested; Teaching and learning Material disposed and the Misconception-Tilde-Treatment which could have adverse effects to the mind of Spanish 2L learners leading to distortion and inadequate Language-Learning-Retention. For this reason the study exposed and discussed the significant of the methodology provided in this research article as appropriate vehicle in teaching and learning the Graphical Accentuation-themes highlighted. This reference-method has already been used in Spanish language classes conducted at Multimedia University (Malaysia) among students from level A1. The results of the application of this method have showed a significant improvement in the acquisition and develop of cognitive skills and language competences regarding to the use of the tildes in Spanish language. Thus, this study discussed the significant of applying these 
graphical-accentuation-forms through methodologies like those provided in this research article. This Spanish-orthography-topic is not to be taught and acquired through an inductive method only, but by a combination of inductive and deductive approaches. The level of complexities that the use of the "tilde" presents in the Writing System of Spanish Language is simply a challenge subject-matter, which involves also Spanish orthography linguistic rules and exceptions and Spanish orthography modifications made and addressed by the Spanish Royal Academic. Appropriately speaking, understanding, digesting and getting to master the use of the tilde in Spanish Language Context it has to be a subject of a constant and practical study, not only for non-native speakers but for native speakers as well. Generally, this is focused "Spanish-orthography-topic", and although the degree of difficulty that it presents can be considered complex, it cannot be dismiss due to its implication in language-use as appropriate.

\section{Conclusion}

On examining the data provided throughout the headings and sub-headings in this research article, one could conclude that the manuscript contains significant literature sources corresponding to the main objective of the research article. The data presented in the manuscript contextualize clearly the subject-matter (Spanish-language-Orthography). In this respect the study has presented a suitable literature material and methods with emphasis on Spanish Language Orthography such as Words-Type; Accents-Type; Vocabulary and Grammar-Patterns. Based on these linguistic-traits significant finding-results have been drawn in attempting to catch the attention of Spanish language learners and Spanish language teachers interested in studding and learning about the use of the tilde in Spanish Language. By considering other studies-research-insights about the need to provide accuracy-learning-materials as reference to study this orthography-linguistic-trait; I would say that this study-research is a modest respond to that call and an academic-contribution letting at the disposition of readers and the specialized critics for its evaluation.

\section{Acknowledgement}

The author is very thankful to all the associated personnel in any reference that contributed in/for the purpose of this research.

\section{Conflict of Interest}

The research holds no conflict of interest.

\section{Funding}

The research is not funded through any source.

\section{References}

American Council on the Teaching of Foreign Languages, (2012). (ACTFL) https://www.actfl.org/publications/guidelines-and-manuals/actfl-proficiency-guidelines-2012

August, D., Calderón M., \& Carlo M. (2002). The Transfer of Skills from Spanish to English: A Study of Young Learners. Center for Applied Linguistics, Washington, D.C.

Capitalization. The Writer's Reference Guide to Spanish. Austin: University of Texas Press. pp. 75-77. ISBN 978-0-292-72511-9. Retrieved September 18, 2014.

Consejo de Europa (2001). Marco Común Europeo de Referencia para las Lenguas: aprendizaje, enseñanza, evaluación. https://www.examenglish.com/CEFR/cefr_es.php

Diccionario de la lengua española 23ª Edición, (2015). Madrid: Espasa. ISBN 978-84-670-4189-7

Eddington, D. (2004). Spanish Phonology and Morphology: Experimental and Quantitative. p. 120. ISBN 9789027215628. ...vowel-final words and those ending in -s are stressed on the penultimate syllable, one would expect the test words to be given penultimate stress... One evidence that quantity sensitivity is relevant in Spanish is cited by Harris $(1983,1992)$. https://doi.org/10.1075/sfsl.53

English Oxford Living Dictionaries (2018). https://languages.oup.com/word-of-the-year/word-of-the-year-2018

Erichson, G. (2012). "Stress and Accent Marks". About.com: Spanish Language. About.com.

Jerry, K. B. (2015). An Easy Comparison Of The English to Spanish Alphabet.

Joshi, R. M., \& Aaron, P. G. (2006). Handbook of Orthography and Literacy. p. 157. ISBN 9781136610813. The normative pattern of accentuation in Spanish is, according to Quilis (1981, pp. 333-336), with the stress on the penultimate syllable. Of words, $79.5 \%$ are paroxytone: these words are stressed on the next-to-the-last syllable

La Vida, R. (1631). Fray de León (español). https://en.wikipedia.org/wiki/Luis_de_Le\%C3\%B3n

Ortografía de la lengua española (2010). Real Academia Española y Asociación de Academias de la Lengua Española. 
p. 63.

Rivera, J. (2019). Spanish Language Grammatical Context-Acknowledging Specific Language Characteristics. Open Journal of Modern Linguistics, 9, 215-228. https://doi.org/10.4236/ojml.2019.93020

\section{Copyrights}

Copyright for this article is retained by the author(s), with first publication rights granted to the journal.

This is an open-access article distributed under the terms and conditions of the Creative Commons Attribution license which permits unrestricted use, distribution, and reproduction in any medium, provided the original work is properly cited. 